\title{
Kinetics of Lawsonia intracellularis antibodies in foals on a breeding farm with equine proliferative enteropathy
}

\author{
Janine Straub', Jil Dohrmann', Rica Wadephul', Alina Singer², Reinhardt Böse'2, Samantha Barnum³, Nicola Pusterla ${ }^{3}$ and Monica Venner ${ }^{4}$ \\ 1 Department of Clinic for Horses, University of Veterinary Medicine Hanover, Foundation, Hanover, Germany \\ 2 Laboratory Dr. Böse GmbH, Harsum, Germany \\ ${ }^{3}$ Department of Medicine and Epidemiology, School of Veterinary Medicine, University of California, Davis, USA \\ ${ }^{4}$ Equine Clinic Destedt GmbH, Destedt, Germany
}

\begin{abstract}
Summary: The objectives of this study were to investigate the kinetics of Lawsonia intracellularis (L. intracellularis) antibodies in foals on a farm with occurrence of equine proliferative enteropathy (EPE) by immunoperoxidase monolayer assay (IPMA). 63 foals were monitored from the age of two to 10 months at two-week intervals via physical examination and selected blood parameters. Serum was used to measure total protein and albumin concentrations as well as antibodies to L. intracellularis by IPMA. In case of hypoproteinaemia and/or hypoalbuminemia, a transabdominal ultrasonographic examination was performed to measure the wall thickness of small intestinal loops. Rectal swabs were taken from foals with suspected EPE to test for $L$. intracellularis by polymerase chain reaction. 55 of the monitored foals developed antibodies against L. intracellularis, only three foals developed EPE. The progressions of the individual antibody titres showed great variability, no specific pattern was observed. Foals with at least two consecutive seropositive samples considering an interval of two weeks did not develop EPE later during the observation period. Four foals showed developments of antibody titres against $L$. intracellularis interrupted by one or two negative serum results. Since there was no uniform titre progression and foals with and foals without EPE showed high antibody titres that were detectable for different lengths of time, it was not possible to conclude the further titre progression in foals based on the kinetics. The results illustrated that a single blood analysis is not always reliable to determine by IPMA whether a foal has been infected with L. intracellularis. Due to technical weaknesses of IPMA, the authors recommend to run all samples in duplicate in order to obtain reliable results on the foal's exposure to $L$. intracellularis for further studies on the kinetics of $L$. intracellularis antibodies and when using the serology as a diagnostic tool for detecting L. intracellularis.
\end{abstract}

Keywords: antibody kinetics, foals, IPMA, Lawsonia intracellularis, serology

Citation: Straub J., Dohrmann J., Wadephul R., Singer A., Böse R., Barnum S., Pusterla N., Venner M. (2022) Kinetics of Lawsonia intracellularis antibodies in foals on a breeding farm with equine proliferative enteropathy. Pferdeheilkunde 38, 127-133; DOI 10.21836/ PEM20220204

Correspondence: PD Dr. Monica Venner PhD, ECEIM, Equine Clinic Destedt GmbH, Trift 4, 38162 Destedt, Germany, mvenner@gmx.de

Submitted: December 3, 2021 | Accepted: January 20, 2022

\section{Introduction}

Lawsonia intracellularis (L. intracellularis) is an obligate intracellular and gram-negative bacterium that can cause equine proliferative enteropathy (EPE) in foals. It affects enterocytes of the small intestine, especially in the ileum, causing hyperplasia of the mucosa and thus thickening of the intestine wall (Lawson and Gebhart 2000). Rodents and Lagomorpha appear to be a possible reservoir for $L$. intracellularis and source of infection for equids (Friedman et al. 2008, Pusterla et al. 2013). Further, clinically and subclinically infected foals contribute to the spread of $L$. intracellularis on endemic farms (Pusterla et al. 2014).

Foals up to the age of one year are particularly susceptible, especially recently weaned foals between four and seven months of age (Lavoie and Drolet 2007, Pusterla et al. 2014). EPE is a seasonal disease with a global distribution, including North America, Europe, Asia and Australia (McClintock and Collins 2004, Frazer 2008, Bohlin et al. 2019, Ueno et al.
2019). Common clinical signs of infected foals are lethargy, anorexia, reduced weight gain, diarrhoea, fever, colic and peripheral oedema. The main parameters for ante-mortem EPE diagnosis are age, clinical signs, hypoproteinaemia caused by hypoalbuminemia and thickening of the small intestine wall visualised by transabdominal sonography. These parameters are considered in combination with antibody detection using serological assays and with molecular detection of $L$. intracellularis in faeces by polymerase chain reaction (PCR) (Lavoie and Drolet 2007, Pusterla et al. 2014). A preventive measure is the vaccination of foals with a porcine avirulent modified-live L. intracellularis vaccine (Pusterla et al. 2012).

As far as the authors are aware, there have been no major studies on antibody kinetics against $L$. intracellularis in foals. Therefore, the aims of this study were to investigate the kinetics of $L$. intracellularis antibodies in foals to explore the course of infection on farms with EPE. The authors decided to perform the serological analysis using the IPMA, which is cited in the literature as the most accurate serological method for 
the determination of $L$. intracellularis antibodies in EPE foals (Gebhart et al. 2012).

\section{Materials and methods}

\section{Study farm and horses}

This study was conducted at a large Warmblood breeding farm in Germany. The mares and their foals lived in groups of 10 to 25 pairs. The foals were weaned from their dams at about six months of age and then kept in large groups of weanlings. None of the study foals showed failure of passive transfer, therefore treatment with equine plasma was not necessary. The status of seropositivity to $L$. intracellularis post-parturition was not determined.

\section{Study design}

The study period began in August 2019 and ended in May 2020. 63 foals were included, comprising 31 colts and 32 fillies, all born in July 2019. The participants were selected as convenience samples based on their date of birth and were kept together with other foals on the farm. The authors expected natural infection with $L$. intracellularis as the farm experienced several cases of EPE in 2018.

From the age of two to 10 months, all foals were physically examined, rectal temperature was measured and blood samples were taken every two weeks. In total, $19 \pm 1$ blood samples were obtained from each of the 63 study foals. Every two weeks, a $4 \mathrm{~mL}$ and a $9 \mathrm{~mL}$ whole blood sample were collected via jugular venepuncture into sterile serum tubes and individvally labelled. The $4 \mathrm{~mL}$ serum tubes were sent to an external laboratory (LABOKLIN GmbH \& Co. KG, Bad Kissingen, Germany) to determine total protein and albumin ( $n=1145)$. The $9 \mathrm{~mL}$ serum tubes were centrifuged at $2.5 \times 1000 \mathrm{~g}$ for 10 minutes, the serum was pipetted into individual labelled $1.5 \mathrm{~mL}$ tubes, and then frozen at $-20^{\circ} \mathrm{C}$ for later serological examinations by IPMA.

If total protein $(<50 \mathrm{~g} / \mathrm{L})$ and/or albumin $(<25 \mathrm{~g} / \mathrm{L})$ concentrations were low, the small intestinal wall thickness was measured by transabdominal ultrasound examination. In case of thickening of the small intestine wall $(>3 \mathrm{~mm})$ together with hypoproteinaemia and clinical signs compatible with EPE (diarrhoea, fever $\geq 39.0^{\circ} \mathrm{C}$, peripheral oedema, lethargy, colic, weight loss or anorexia), a faecal swab was collected and tested for $L$. intracellularis via PCR to support a diagnosis of EPE. Affected foals were treated with antimicrobials and supportive care like equine plasma transfusion, which was not tested for antibodies against $L$. intracellularis.

For logistical reasons, not all serum samples were collected during the entire study period. Three foals were excluded during the study: two foals were sold in January and March, and one foal developed handling difficulties in February. Additionally, a vaccination study against $L$. intracellularis was conducted at the same time. For organisational reasons, it was not possible to strictly separate the foals of both studies over the complete study period.

\section{Serology by IPMA}

The sera of the study foals were examined in batches between November 2019 and June 2020. The first part of serum samples $(n=234)$ was sent in cooled boxes to the Equine Infectious Disease Research Laboratory, University of California, Davis, USA for serological testing. The remaining samples ( $n=923$ ) were examined at the laboratory Dr. Böse $\mathrm{GmbH}$, Harsum, Germany. In both laboratories, all assays were run by one of the authors (JS), who was blinded to the clinical status of the foals. For all samples, IPMA was used as previously described (Gebhart et al. 2012), according to the same standard operating procedures of the Davis laboratory using the same chemical substances. The antigen was extracted from the lyophilized L. intracellularis pig vaccine (Enterisol lleitis, Boehringer Ingelheim Vetmedica).

All samples were first tested at a dilution of $1: 60$. If antibodies were detected at this dilution, the samples were retested and determined to a maximum titre of 960 . The individual samples of one foal were not measured as a complete sample series in one IPMA run, but together with samples of other foals, and were usually spread over several days. Only the complete sample series of four intermittently seropositive foals was tested in one run to rule out test variance in these striking results.

Seroconversion was defined as follows: The serum samples were positive at the dilution $\geq 1: 60$, all samples $<1: 60$ were considered negative (Pusterla et al. 2010). Antibodies against L. intracellularis were regarded as maternal until three months of age (Pusterla et al. 2009a). Maternal antibodies were not considered as seroconversion nor in the number of positive samples.

\section{Statistical analysis}

The investigation and description of antibody kinetics as well as the number of seropositive samples and the occurrence of seroconversions were mainly descriptive analyses. Correlation analysis was performed according to Spearman. The association between high antibody titres and EPE disease was assessed using Fisher's exact test.

\section{Results}

55 foals $(87.3 \%)$ seroconverted during the study period, most in January (58.2\%) and March (18.2\%). Three of these foals (5.5\%) developed EPE (Fig. 1), diagnosed by hypoproteinaemia $(<50 \mathrm{~g} / \mathrm{L}, 3 / 3)$, hypoalbuminemia $(<25 \mathrm{~g} / \mathrm{L}, 3 / 3)$, thickened small intestinal walls $(>3 \mathrm{~mm}, 3 / 3)$, clinical signs (weakness $2 / 3$, fever $1 / 3$ ) and PCR result ( $2 / 3$ positive). The PCR result of the third foal was negative, however, antimicrobial treatment had already been started at the time of faecal collection. Eight foals (12.7\%) showed no seroconversion, one of them had maternal antibodies.

Considering the serum proteins, $3.1 \%$ of the total protein valves were lower than $50 \mathrm{~g} / \mathrm{L}$ and $2 \%$ of the albumin values were lower than $25 \mathrm{~g} / \mathrm{L}$. In total, 40 foals showed EPE-associated clinical signs including fever $\left(\geq 39.0^{\circ} \mathrm{C}\right)$ at least once during the study period, 14 of them related to Lawsonia-spe- 
cific antibodies. In five foals thickened walls of the small intestine $(>3 \mathrm{~mm}$ ) were visualised by ultrasound.

In total, 378 serum samples (32.7\%) showed antibodies against $L$. intracellularis, with titres ranging from 60 to 960 . Additionally, 31 seropositive samples (2.7\%) in 13 foals were considered as maternally-derived antibodies. One foal was consistently seropositive from the beginning of the study, so that no differentiation between maternal antibodies and seroconversion was possible. This foal was not included in the assessment of the antibody titre progression. None of its positive samples were considered to be maternal antibodies in the further evaluations.

The data set of 22 foals was incomplete, with 41 serum samples missing of the planned 1198 samples. Thereby, four foals were missing a sample during the antibody titre progression and six foals were missing the sample directly before seroconversion. In these six foals, the first seropositive sample was regarded as the time of seroconversion. For the characterisation of the antibody titre progressions, these six foals were not considered.

The kinetics of the antibodies showed many different patterns; no uniform kinetics were observed. The antibody titre developments were assigned to four different progressions in order to illustrate the inconsistent titre courses in a certain structure (Fig. 2). Progression 1 (27.1\%, 13/48) reflected the kinetics with the highest antibody titre of this foal at seroconversion, which then formed a plateau or directly decreased in the further progression and then some of them plateaved. Progression $2(25 \%, 12 / 48)$ showed the kinetics with an initial increase in antibody titre, followed by a plateau or directly decrease and possibly one or more increases later in the progression. Progression $3(37.5 \%, 18 / 48)$ presented the kinetics in which the antibody titre often initially remained on a plateau or dropped directly and then rose again at least once later in the development. Progression 4 (10.4\%,5/48) reflected

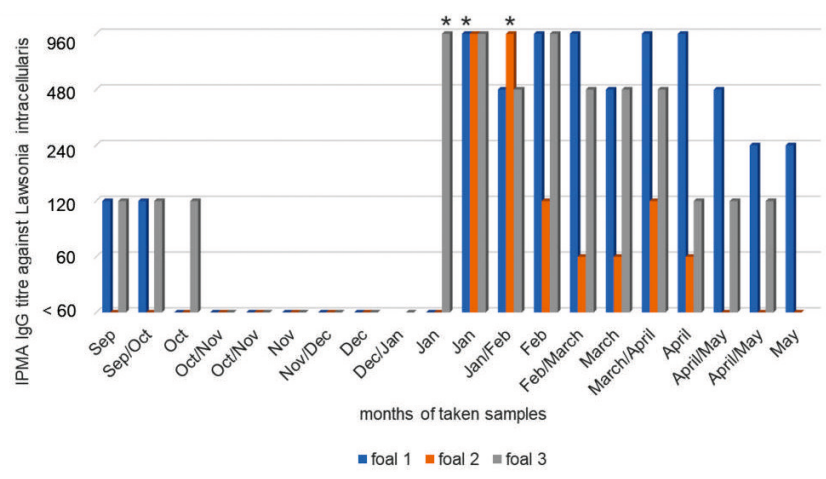

Fig. 1 Kinetics of the antibody titre courses against Lawsonia intracellularis in the three study foals suffering from equine proliferative enteropathy (EPE). The star marks the sample from each foal closest to the day of diagnosis EPE. Dec: December, Feb: February, IPMA: Immunoperoxidase monolayer assay, Jan: January, Sep: September, Oct: October, Nov: November. | Kinetik der Antikörpertiterverläufe gegen Lawsonia intracellularis bei den drei an equiner proliferativer Enteropathie (EPE) erkrankten Studienfohlen. Der Stern markiert bei jedem Fohlen die Probe, die dem Tag der Diagnosestellung EPE am nächsten liegt. Dez: Dezember, Feb: Februar, IPMA: Immunoperoxidase Monolayer Assay, Jan: Januar, Sep: September, Okt: Oktober, Nov: November. the kinetics in which the titre remained stable across samples, including foals with seropositivity in only one sample.

The number of seropositive foals increased strongly in the months from January to May, with a peak in March (90.6\%). Overall, high antibody titres (480 or 960) were detected in 39 seroconverted foals (70.9\%), from one to 10 samples consecutively. 29 of these foals (74.4\%) showed high antibody titres in their first seropositive tested sample. The association between high titres (480 or 960) and developing EPE was not significant $(p=0.28)$.

High antibody titres (480 or 960) and the duration of antibody detection in weeks were positively correlated $(r=0.67)$. Seropositivity was observed on average over seven consecutive samplings over a duration of about 12 weeks, as there was not always an interval of two weeks between samplings. Foals with intermittent antibody titre were not included. For the

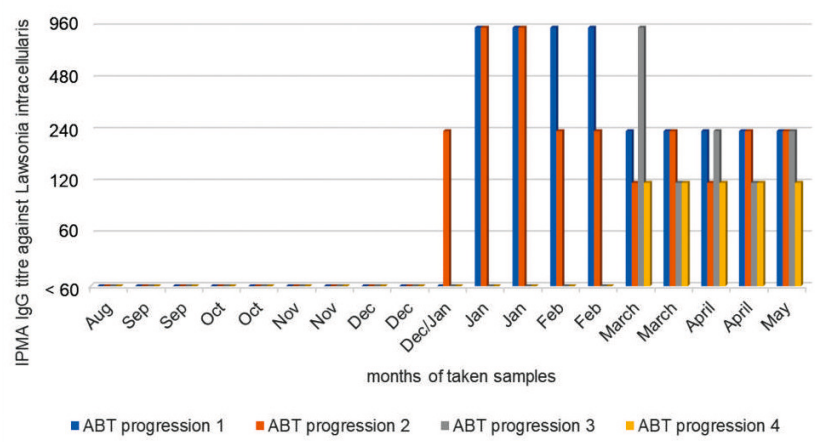

Fig. 2 Example of the four observed progressions of antibody titres (ABT) against Lawsonia intracellularis. Each of these progressions is illustrated using the individual antibody titre progression of one study foal as example. Progression $1(27.1 \%, 13 / 48)$ reflected the kinetics with the highest antibody titre of this foal at seroconversion, which then remained on a plateau or directly decreased in the further progression and then partially plateaved. Progression 2 (25\%, $12 / 48$ ) showed the kinetics with an initial increase in antibody titre, followed by a plateau or directly decrease and possibly one or more increases later in the progression. Progression $3(37.5 \%, 18 / 48)$ presented the kinetics in which the antibody titre often initially remained on a plateau or dropped directly and then rose again at least once later in the development. Progression 4 (10.4\%, 5/48) reflected the kinetics in which the titre remained stable across samples, including foals with seropositivity in only one sample. Aug: August, Dec: December, Feb: February, IPMA: Immunoperoxidase monolayer assay, Jan: January, Sep: September, Oct: October, Nov: November. Beispiel für vier beobachtete Verläufe des Antikörpertiters (AKT) gegen Lawsonia intracellularis. Jeder dieser Verläufe wird am Beispiel des individuellen AKT-Verlaufs eines Studienfohlens dargestellt. Verlauf 1 $(27,1 \%, 13 / 48)$ spiegelte die Kinetik mit dem höchsten AKT dieses Fohlens bei der Serokonversion wider, der dann ein Plateau bildete oder im weiteren Verlauf direkt abnahm und dann teilweise auf einem Plateau endete. Verlauf 2 (25\%, 12/48) zeigte die Kinetik mit einem anfänglichen Anstieg des AKT auf, gefolgt von einem Plateau oder einem direkten Rückgang und möglicherweise einem oder mehreren Anstiegen in der weiteren Entwicklung. Verlauf 3 (37,5\%, 18/48) gab die Kinetik wieder, bei der der AKT häufig zunächst auf einem Plateau verharrte oder direkt abfiel und dann im späteren Verlauf mindestens einmal erneut anstieg. Verlauf $4(10,4 \%, 5 / 48)$ spiegelte die Kinetik wider, bei der der Titer über die Proben hinweg stabil blieb, einschließlich Fohlen mit Seropositivität in nur einer Probe. Aug: August, Dez: Dezember, Feb: Februar, IPMA: Immunoperoxidase-MonolayerAssay, Jan: Januar, Sep: September, Okt: Oktober, Nov: November. 
four foals with a missing sample during the titre progression, this sample was considered positive. One foal showed antibodies with titres ranging from 60 to 960 for 33 weeks, possibly including maternal antibodies. $29.1 \%$ of the foals (16/55) showed antibody titres of 60 to a maximum of 240 over one to 13 consecutive samples. $87.3 \%$ of the seroconverted foals $(48 / 55)$ were seropositive in at least two consecutive samples approximately two weeks apart without developing EPE at a later stage of the study period. $54.5 \%$ of the seroconverted foals (30/55) were still positive in their last sample, either when they left the study or at the end of the observation period. Table 1 shows an age-based examination of seropositivity to $L$. intracellularis in foals.

About $8.6 \%$ of the samples required one or more retests due to result discrepancy or unclear results caused by strong background during microscopic evaluation. Some samples were initially positive but negative in the same dilutions when retested up to higher dilution levels. Three foals with intermittent seropositivity showed single negative samples in between, one foal showed two consecutive negative samples. The antibody titres before and after these seronegative samples were either 60 or 120 in all four foals. Despite multiple testing of these negative samples $(n=6)$ in the otherwise positive sample histories, no clear, reproducible results were obtained. However, the foals were included in the evaluation of the antibody titre progressions.

\section{Discussion}

This study presents the first investigation of antibody kinetics against $L$. intracellularis in foals on a farm in Germany. $87.3 \%$ of the study foals had contact with the pathogen, as deduced from the serological detection of antibodies against
L. intracellularis. Most seroconversions occurred in January as previously reported (Page et al. 2011). The current results supported the assumption of Pusterla et al. (2008) that a detectable antibody response commonly occurs in foals without clinical EPE as only $5.5 \%$ of all seroconverted study foals developed clinical EPE. 40 foals showed EPE-associated signs, 14 of them related to Lawsonia-specific antibodies, but only three foals contracted this disease. This illustrated that EPE-associated signs are very non-specific and that positive serology alone is not conclusive. Therefore, it is important to consider always all parameters such as serology, total protein concentration and clinical signs in conjunction (Pusterla et al. 2014).

As EPE had been observed on that farm since 2018, the infection in the study foals was most likely due to natural exposure to the pathogen $L$. intracellularis. The study was carried out at the same time as a vaccination study against $L$. intracellularis at the farm. For organisational reasons, it was not possible to strictly separate the foals of both studies. Therefore, it must be questioned whether some foals became infected with the pathogen via the faeces of vaccinated foals. The authors singled out all locations during the sampling period for each foal of the current study and compared when the foals were in the same herd with a foal vaccinated against $L$. intracellularis. This was done by considering the time window in which vaccinated foals could potentially have shed the pathogen and in which non-vaccinated foals developed antibodies against L. intracallularis. Vaccinated foals excrete the pathogen only after the first vaccination, starting 11 to 15 days after vaccination and lasting between one and 12 days (Pusterla et al. $2009 b)$. Since there is no proof of how long the vaccinated pathogen survives in the environment, one must at least consider in this case that the vaccinated pathogen can survive in the environment for up to two weeks, just like the natural

Table 1 Age-based view of seropositivity to Lawsonia intracellularis in foals. | Altersabhängige Betrachtung der Seropositivität für Lawsonia intracellularis bei Fohlen.

\begin{tabular}{|c|c|c|c|c|c|c|c|c|}
\hline \multirow{2}{*}{$\begin{array}{l}\text { Age in weeks } \\
\text { ( } \pm 1 \text { week) }\end{array}$} & \multirow{2}{*}{$\begin{array}{l}\text { number of sero- } \\
\text { positive foals (titre } \\
\quad \geq 60 \text { ) }\end{array}$} & \multirow{2}{*}{$\begin{array}{l}\text { number of sero- } \\
\text { negative foals } \\
\text { (titre }<60 \text { ) }\end{array}$} & \multirow{2}{*}{$\begin{array}{l}\text { number of sampled } \\
\text { foals at that age }\end{array}$} & \multicolumn{5}{|c|}{ number of dilution at each age } \\
\hline & & & & $1: 60$ & $1: 120$ & $1: 240$ & $1: 480$ & $1: 960$ \\
\hline $8^{a}$ & 14 & 49 & 63 & 2 & 9 & 1 & 1 & 1 \\
\hline $12^{a}$ & 7 & 56 & 63 & 4 & 3 & 0 & 0 & 0 \\
\hline $16^{b}$ & 2 & 60 & 62 & 0 & 1 & 1 & 0 & 0 \\
\hline 20 & 3 & 60 & 63 & 1 & 1 & 0 & 0 & 1 \\
\hline $24^{c}$ & 10 & 40 & 50 & 2 & 3 & 1 & 2 & 2 \\
\hline $28^{b}$ & 31 & 31 & 62 & 1 & 7 & 6 & 3 & 14 \\
\hline $32^{b / d}$ & 41 & 20 & 61 & 5 & 11 & 3 & 9 & 13 \\
\hline $36^{b / e}$ & 44 & 15 & 59 & 18 & 11 & 4 & 6 & 5 \\
\hline 40 & 36 & 24 & 60 & 13 & 11 & 5 & 2 & 5 \\
\hline $44^{\mathrm{b} / \mathrm{f}}$ & 22 & 30 & 52 & 4 & 10 & 5 & 2 & 1 \\
\hline \multicolumn{9}{|c|}{$\begin{array}{l}\text { This age included presumably maternal antibodies. I Dieses Alter beinhaltet vermutlich auch maternale Antikörper. } \\
\text { b For one foal no sample could be collected. I Bei einem Fohlen konnte keine Probe entnommen werden. } \\
\text { c No sample could be taken from } 13 \text { foals. I Bei } 13 \text { Fohlen konnte keine Probe entnommen werden. } \\
\text { d One foal was sold at that age, it was not included anymore. I Ein Fohlen wurde in diesem Alter verkauft und somit nicht mehr berücksichtigt. } \\
\text { e One foal was sold at that age and one more left the study; both were not included anymore. I Ein Fohlen wurde in diesem Alter verkauft und ein weiteres verließ die } \\
\text { Studie; beide wurden nicht mehr berücksichtigt. } \\
\text { the sampling of eight foals had already been ended with the previous sample. | Die Beprobung von acht Fohlen endete bereits mit der vorangegangenen Proben- } \\
\text { nahme. }\end{array}$} \\
\hline
\end{tabular}


pathogen (Collins et al. 2000). Unvaccinated foals seroconvert 14 to 21 days after exposure to the pathogen (Pusterla et al. 2010). After taking all these findings into account, an infection via the faeces of foals recently vaccinated with the live $L$. intracellularis vaccine could not completely be ruled out in five study foals in connection with the temporal occurrence. However, Pusterla et al. (2012) showed that vaccinated foals shed significantly less $L$. intracellularis in their faeces compared to non-vaccinated foals. Furthermore, there are no studies to date on whether this excreted amount of L. intracellularis is sufficient to infect a naïve foal and how long the vaccine pathogen survives in the environment. The minimal infectious dose for foals is unknown and needs to be investigated in a follow-up study. Additionally, foals vaccinated orally (without gastric protection) against $L$. intracellularis rarely develop a measurable immune response (Pusterla ef al. 2009b). Thus, the likelihood of a naïve foal becoming infected with the vaccine pathogen shed by rectally vaccinated foals, as practised in the vaccination programme at the stud, is very low. Another point that underscores this statement is that all eight foals in the current study that did not undergo seroconversion were also at times with vaccinated foals. Nevertheless, it is advisable to a strict separation of vaccinated and non-vaccinated foals in future studies in order to completely avoid a certain questionability.

Due to the different kinetics of the antibody titres against $L$. intracellularis in this study, no uniform pattern was observed. Some titres dropped after reaching a peak, others plateaved over several samplings and some dropped and rose again at a later time period. This observation was not consistent with the previous finding in pigs that the titre drops gradually after reaching a peak (Guedes 2004). Therefore, no statement about the further progression of the titre can be made on the basis of individual samples. The reason for the different developments of the titres can be manifold. Although this has not yet been investigated in foals, it cannot be ruled out that a renewed exposure to the pathogen $L$. intracellularis leads to an increase in the antibodies already formed. Since the number of foals on this farm was large $(n>1000)$, frequent mixing of the individual herds took place and the pathogen can survive in the environment for up to two weeks, a high infection pressure can be assumed (Collins et al. 2000). In addition, the immune status of the individual foals was not known, which influences the formation of antibodies in the case of existing immunosuppression. Furthermore, a previous study showed that horses infected with a species-specific isolate of $L$. intracellularis developed a stronger immune response (Vannucci et al. 2012). In the current study, it cannot be differentiated whether the foals were infected with a species-specific isolate or some of them with a non-species-specific isolate, which can consequently lead to the different titre progressions. Moreover, it has to be considered that the serological examinations of the samples of the individual foals were carried out on different days and thus it can be assumed that the inter-assay variation of the IPMA had an influence on the present results. The authors found no data on the inter-assay variation of IPMA in other studies.

Many foals (70.9\%) showed high antibody titres (480 or 960), but, only three of them developed EPE. The finding that a high titre appears to be associated with clinical disease could not be observed in the current study (Pusterla et al. 2010). Two foals with clinical EPE had high titres that remained for 12 and 13 weeks, respectively, followed by lower titres. One of these EPE foals had received several plasma transfusions. Possibly the plasma contained antibodies against $L$. intracellularis and thus influenced the long-lasting high antibody titre. However, a positive correlation between high antibody titres and the duration of detectable antibodies, as observed in pigs with porcine proliferative enteropathy (PPE), was confirmed with our results (Guedes 2004).

The average duration of detectable seropositivity in this study was about 12 weeks. One foal showed antibodies for almost eight months, confirming the findings of a previous study in which one foal still showed antibodies after six months (Dauvillier et al. 2006). In PPE affected pigs, antibodies were still detectable up to three months after the disease (Guedes et al. 2002). It appears that antibodies against $L$. intracellularis are partially detectable longer in foals than in pigs. Longer periods of antibody detection against $L$. intracellularis in foals were not only observed in clinically infected animals.

The current results showed that in case of seropositivity at a single time point, the development of EPE cannot be excluded. Since only three of the 63 foals showed a clinical EPE, no meaningful statement about the kinetics of the antibody titre in EPE foals was possible. In two foals, antibodies were detected before diagnosis, in one foal two days and in the other foal 10 days before diagnosis. In the third foal, EPE was diagnosed three days before seroconversion was detected. However, based on the data, it is not possible to assess whether this foal actually seroconverted first and only developed clinical signs of EPE later, as sampling only took place every two weeks and thus earlier seroconversion cannot be ruled out. But, the authors noted that foals ( $n=48$ ) with at least two consecutive seropositive results, considering an interval of two weeks, did not develop EPE at any later time of the observation period. Due to the overall low attack rate in the current study, further studies are needed to assess whether two consecutive seropositive samples are indeed unlikely to result in the later development of EPE.

According to Gebhart et al. (2012), the IPMA is the most precise serological method for the determination of antibodies against $L$. intracellularis in foals with EPE. However, the IPMA showed some technical weaknesses in the analysis of the serum samples. About $8.6 \%$ of the samples had to be tested multiple times due to strong background in microscopic evalvation or result discrepancy. The latter occurred mainly in seropositivity at the different dilution levels. The reliability of the test procedure also had to be questioned with regard to the intermittent antibody titre progression of four foals. In three foals, single seronegative samples and in one foal two consecutive seronegative samples occurred during their positive antibody titre course. No clearly reproducible results could be obtained in the test replicates of these samples. When interpreting the results, it must be noted that there is always a certain test variance in laboratory diagnostic examinations of samples as well as an inter-assay variation. Due to the time component in performing the IPMA and the number of samples examined, the examinations of the individual samples in different dilutions mostly took place over several days. Never- 
theless, a limitation of this study is that not all samples were tested as duplicates by default as the test procedure turned out to be not entirely reliable during the examination of the samples. The authors must critically question to what extent the results obtained really correspond to the true result of the samples in terms of the level of antibody titres. For future studies of antibody kinetics against $L$. intracellularis and also for serological analyses, the authors recommend testing all samples in duplicate to obtain reliable results of the antibody titre.

\section{Conclusions}

When studying the kinetics of antibodies against L. intracellularis in foals, many different progressions of antibody titres were observed. Since there was no uniform titre course and both, foals with and without EPE, showed high antibody titres that were detectable for different lengths of time, it was not possible to conclude from the kinetics on the further titre progression. However, the results showed that none of the foals with two consecutive seropositive samples, considering an interval of two weeks, developed EPE at any later time of the observation period. The data demonstrated that a single serological testing by IPMA was not always reliable to determine whether a foal had been infected by L. intracellularis. The authors recommend to run all samples in duplicate in order to obtain reliable results on the foal's exposure to $L$. intracellularis when using the IPMA as a diagnostic tool for detecting $L$. intracellularis and for further studies of their kinetics. It is important to always interpret positive serological results with clinical signs and biochemical abnormalities.

\section{Conflict of interest statement}

None of the authors has any financial or personal relationships that could inappropriately influence or bias the content of the paper.

\section{Animal welfare statement}

The study was reviewed and approved by the Animal Welfare Officer of the University of Veterinary Medicine Hanover on 27 November, 2019 with the file number TVO-2019-V-105.

\section{References}

Bohlin A. M., Nautrup Olsen S., Laursen S. H., Öhman A., van Galen G. (2019) Lawsonia intracellularis associated equine proliferative enteropathy in Danish weanling foals. Acta Vet. Scand. 61, 12; DOI 10.1186/s13028-019-0447-3

Collins A., Love R. J., Pozo J., Smith S. H., McOrist S. (2000) Studies on the ex vivo survival of Lawsonia intracellularis. Swine Health Prod. 8, 211-215

Dauvillier J., Picandet V., Harel J., Gottschalk M., Desrosiers R., Jean D., Lavoie J. P. (2006) Diagnostic and epidemiological features of Lawsonia intracellularis enteropathy in 2 foals. Can. Vet. J. 47, 689-691

Frazer M. L. (2008) Lawsonia intracellularis Infection in Horses: 2005 -2007. J. Vet. Intern. Med. 22, 1243-1248; DOI 10.1111/j.19391676.2008.0160.x
Friedman M., Bednar V., Klimes J., Smola J., Mrlik V., Literak I. (2008) Lawsonia intracellularis in rodents from pig farms with the occurrence of porcine proliferative enteropathy. Appl. Microbiol. 47, 117-121; DOI 10.1111/j.1472-765X.2008.02394.x

Gebhart C., Page A. E., Kelley M., Chander Y., Mapes S., White A., Horohov D. W., Pusterla N. (2012) Comparative Study of Serology Assays for Equine Proliferative Enteropathy. Am. Assoc. Equine Pract. Proceedings 58

Guedes R., Gebhart C., Armbruster G. A., Roggow B. D. (2002) Serologic follow-up of a repopulated swine herd after an outbreak of proliferative hemorrhagic enteropathy. Can. J. Vet. Res. 66, 258-263

Guedes R. (2004) Update on epidemiology and diagnosis of porcine proliferative enteropathy. Swine Health Prod. 12, 134-138

Lavoie J. P., Drolet R. (2007) Lawsonia intracellularis In: Equine Infectious Diseases, First Edn. Saunders Elsevier, St. Louis, MO, USA, 313-316

Lawson G. H. K., Gebhart C. J. (2000) Proliferative Enteropathy. Comp. Pathol. 122, 77-100; DOI 10.1053/icpa.1999.0347

McClintock S. A., Collins A. M. (2004) Lawsonia intracellularis proliferative enteropathy in a weanling foal in Australia. Aust. Vet. J. 82, 750-752

Page A. E., Stills H. F., Chander Y., Gebhart C. J., Horohov D. W. (2011) Adaptation and validation of a bacteria-specific enzyme-linked immunosorbent assay for determination of farm-specific Lawsonia intracellularis seroprevalence in central Kentucky Thoroughbreds. Equine Vet. J. 43, 25-31; DOI 10.1111/i.20423306.201 1.00487.x

Pusterla N., Higgins J. C., Smith P., Mapes S., Gebhart C. (2008) Epidemiological survey on farms with documented occurrence of equine proliferative enteropathy due to Lawsonia intracellularis. Vet. Rec. 163, 156-158; DOI 10.1136/vr.163.5.156

Pusterla N., Jackson R., Wilson R., Collier J. R., Mapes S., Gebhart C. (2009a) Temporal detection of Lawsonia intracellularis using serology and real-time PCR in Thoroughbred horses residing on a farm endemic for equine proliferative enteropathy. Vet. Microbiol. 136, 173-176; DOI 10.1016/i.vetmic.2008.10.004

Pusterla N., Hilton H., Wattanaphansak S., Collier J. R., Mapes S. M., Stenbom R. M., Gebhart C. (2009b) Evaluation of the humoral immune response and fecal shedding in weanling foals following oral and intra-rectal administration of an avirulent live vaccine of Lawsonia intracellularis. Vet. J. 182, 458-462; DOI 10.1016/i. tvjl.2008.08.016

Pusterla N., Wattanaphansak S., Mapes S., Collier J. R., Hill J., DiFrancesco M., Gebhart C. (2010) Oral Infection of Weanling Foals with an Equine Isolate of Lawsonia intracellularis, Agent of Equine Proliferative Enteropathy. J. Vet. Intern. Med. 24, 622-627; DOI 10.1111/j.1939-1676.2010.0482.x

Pusterla N., Vannucci F. A., Mapes S. M., Nogradi N., Collier J. R., Hill J., DiFrancesco M., White A. M., Akana K. A., Simonek G., et al. (2012) Efficacy of an avirulent live vaccine against Lawsonia intracellularis in the prevention of proliferative enteropathy in experimentally infected weanling foals. Am. J. Vet. Res. 73, 741-746

Pusterla N., Sanchez-Migallon Guzman D., Vannucci F. A., Mapes S., White A., DiFrancesco M., Gebhart C. (2013) Transmission of Lawsonia intracellularis to weanling foals using feces from experimentally infected rabbits. Vet. J. 195, 241-243; DOI 10.1016/i. tvjl.2012.05.028

Pusterla N., Gebhart C., Lavoie J. P., Drolet R. (2014) Lawsonia intracellularis. In: Equine Infectious Diseases, 2nd Edn. Saunders Elsevier, St. Louis, MO, USA, pp. 316-321

Ueno Y., Uemura R., Niwa H., Higuchi T., Sekiguchi S., Sasaki Y., Sueyoshi M. (2019) Total serum protein reference value as a clinical diagnostic index of equine proliferative enteropathy. Jap. Soc. Equine Sci. 30, 63-67; DOI 10.1294/jes.30.63

Vannucci F. A., Pusterla N., Mapes S. M., Gebhart C. (2012) Evidence of host adaptation in Lawsonia intracellularis infections. Vet. Res. 43, 53; DOI 10.1186/1297-9716-43-53 


\section{Die Kinetik von Lawsonia intracellularis-Antikörpern bei Fohlen in einem Zuchtbetrieb mit equiner proliferativer Enteropathie}

Die equine proliferative Enteropathie (EPE) ist eine heutzutage immer häufiger auftretende Erkrankung bei Fohlen. Verantwortlich dafür ist das obligat intrazelluläre Bakterium Lawsonia intracellularis (L. intracellularis). Infizierte Fohlen zeigen Symptome wie Fieber, Durchfall, Lethargie, Anorexie, Ödeme, Kolik und eine verminderte Gewichtszunahme. Ein weiterer wichtiger Parameter dieser Erkrankung ist das Vorliegen einer Hypoproteinämie. Bei der Diagnostik werden zusätzlich der serologische Nachweis von Antikörpern gegen L. intracellularis, zum Beispiel mittels eines Immunoperoxidase Monolayer Assays (IPMA), und der molekulare Nachweis des Erregers im Kot mittels einer Polymerasen Kettenreaktion (PCR) angewendet.

Ziel dieser Studie war es, die Kinetik von Antikörpern gegen L. intracellularis bei Fohlen auf einem großen Warmblut-Gestüt in Deutschland zu untersuchen, auf dem es in der Vergangenheit nachweislich Fälle von EPE gab. Für die serologische Untersuchung der Proben wurde der IPMA als Testverfahren ausgewählt.

Im Rahmen der Studie wurden 63 Fohlen, die alle im Juli 2019 auf dem Gestüt geboren wurden, im Alter von zwei bis 10 Monaten im zweiwöchentlichen Rhythmus durch die Entnahme einer Blutprobe beprobt, klinisch untersucht und deren Körperinnentemperatur wurde rektal gemessen. Insgesamt wurden von jedem der 63 Studienfohlen $19 \pm 1$ Blutproben jeweils mit zwei sterilen Serumröhrchen entnommen. Nach jeder Probenentnahme wurde ein Serumröhrchen pro Fohlen an ein externes Labor geschickt, zur Bestimmung der Konzentration von Gesamtprotein und Albumin. Im Falle einer vorliegenden Hypoproteinämie $(<50 \mathrm{~g} / \mathrm{L})$ und/oder Hypoalbuminämie $(<25 \mathrm{~g} / \mathrm{L})$ wurde die Dünndarmwand des betroffenen Fohlens transabdominal mit Hilfe einer ultrasonographischen Untersuchung auf eine Verdickung (>3 mm) untersucht. Sofern eine Hypoproteinämie/Hypoalbuminämie und eine Verdickung der Dünndarmwände vorlag, wurde ein Kottupfer mittels PCR auf das Bakterium L. intracellularis untersucht. Das jeweils zweite Serumröhrchen wurde zentrifugiert und das daraus gewonnene Serum wurde anschließend bei $-20^{\circ} \mathrm{C}$ für spätere serologische Untersuchungen eingefroren. Alle Serumproben wurden durch eine der Autorinnen (JS) mittels des IPMA auf Antikörper gegen L. intracellularis untersucht. Zunächst wurden alle Proben in einer 1:60 Verdünnung getestet. Sofern in dieser Verdünnung Antikörper gegen L. intracellularis nachweisbar waren, wurde die Probe in höheren Verdünnungsstufen untersucht, bis maximal zu einer Verdünnung von 1:960. Eine Serokonversion lag vor, wenn die Probe in einer Verdünnung von $\geq 1: 60$ Antikörper gegen L. intracellularis aufwies. Proben, die in der Verdünnung 1:60 keine Antikörper aufzeigten, wurden als seronegativ gewertet und nicht weiter untersucht. Obwohl zeitgleich auf dem Gestüt eine Impfstudie gegen L. intracellularis durchgeführt wurde, gehen die Autoren davon aus, dass die Fohlen dieser Studie dem Erreger auf natürlichem Weg ausgesetz† waren. Eine Exposition gegenüber L. intracellularis durch die Ausscheidung des Erregers durch geimpfte Fohlen konnte bei fünf Studienfohlen jedoch aufgrund zeitlicher Zusammenhänge nicht vollkommen ausgeschlossen werden.

Im Laufe der Studie serokonvertierten insgesamt 55 Fohlen (87,3\%), wobei nur drei dieser Fohlen an einer klinischen EPE erkrankten. Insgesamt wurden in 378 Serumproben (32,7\%) Antikörper gegen L. intracellularis mit Titern zwischen 60 und 960 nachgewiesen. Zusätzlich wurden 31 seropositive Proben (2,7\%) bei 13 Fohlen als maternale Antikörper gewertet. Der Verlauf der Antikörpertiter zeigte viele verschiedene Muster, es wurde jedoch keine einheitliche Kinetik beobachtet. Um die unregelmäßigen Titerverläufe zu veranschaulichen, ordneten die Autoren die Antikörpertiterentwicklungen vier verschiedenen Mustern zu. Verlauf 1 (27,1%, 13/48) spiegelte die Kinetik mit dem höchsten Antikörpertiter dieses Fohlens bei der Serokonversion wider, der dann ein Plateau bildete oder im weiteren Ablauf direkt abnahm und sich erst dann zum Teil auf einem Plateau stabilisierte. Verlauf 2 (25\%, 12/48) zeigte die Kinetik mit einem anfänglichen Anstieg des Antikörpertiters, gefolgt von einer Plateaubildung oder einem direkten Rückgang und möglicherweise einem oder mehreren Anstiegen in der weiteren Entwicklung. Verlauf 3 (37,5\%, 18/48) gab die Kinetik wieder, bei der der Antikörpertiter häufig zunächst auf einem Plateau verharte oder direkt abfiel und dann später im Verlauf mindestens einmal wieder anstieg. Verlauf 4 (10,4\%,5/48) spiegelte die Kinetik wider, bei der der Titer über mehrere Proben hinweg stabil blieb, einschließlich Verläufe mit nur einer einzelnen seropositiven Probe. Es gab keinen signifikanten Zusammenhang zwischen hohen Titern (480 oder 960) und der Entwicklung von EPE ( $p=0,28)$. Insgesamt wurden bei 39 serokonvertierten Fohlen $(70,9 \%)$ hohe Antikörpertiter (480 oder 960) festgestellt, und zwar in einer bis 10 aufeinanderfolgenden Proben. 29 dieser Fohlen (74,4\%) wiesen in ihrer ersten seropositiven Probe hohe Antikörpertiter auf. Hohe Antikörpertiter (480 oder 960) und die Dauer des Antikörpernachweises in Wochen korrelierten positiv $(r=0,67)$. Die Seropositivität wurde im Durchschnitt bei sieben aufeinanderfolgenden Probenahmen über einen Zeitraum von etwa 12 Wochen festgestellt, wobei die Zeitspanne zwischen zwei Probennahmen nicht immer zwei Wochen entsprach. In dieser Studie entwickelte keines der Fohlen mit mindestens zwei aufeinanderfolgenden seropositiven Proben im Abstand von zwei Wochen im späteren Verlauf des Beobachtungszeitraums EPE. Der IPMA zeigte im Laufe der Studie einige technische Schwächen. Bei etwa 8,6\% der Proben waren ein oder mehrere Wiederholungstests erforderlich, da aufgrund des starken Hintergrundgeschehens bei der mikroskopischen Untersuchung keine eindeutigen Ergebnisse auszuwerten waren oder Diskrepanzen zu dem vorherigen Testergebnis vorlagen. Einige Proben waren zunächst positiv, dann aber in denselben Verdünnungen negativ, als sie im Rahmen höherer Verdünnungsstufen erneut getestet wurden. Drei Fohlen mit intermittierender Seropositivität zeigten im Antikörperverlauf einzelne negative Proben, ein Fohlen sogar zwei aufeinanderfolgende negative Proben. Die Antikörpertiter vor und nach diesen seronegativen Proben betrugen bei allen vier Fohlen entweder 60 oder 120 . Trotz mehrfacher Untersuchung dieser negativen Proben $(n=6)$ der vier Fohlen innerhalb deren positiver Titerverläufe konnten keine eindeutigen, reproduzierbaren Ergebnisse erzielt werden.

Die vorliegende Studie zeigt auf, dass bei der Untersuchung der Antikörperkinetik gegen L. intracellularis bei Fohlen viele unterschiedliche Verläufe von Antikörpertitern beobachtet wurden. Da es keinen einheitlichen Titerverlauf gab und sowohl Fohlen mit als auch ohne EPE hohe Antikörpertiter aufwiesen, die unterschiedlich lange nachweisbar waren, war es nicht möglich, anhand der Kinetik auf den weiteren Titerverlauf bei Fohlen zu schließen. Die Ergebnisse zeigten jedoch, dass keines der Fohlen mit mindestens zwei aufeinanderfolgenden seropositiven Proben im Abstand von etwa zwei Wochen zu einem späteren Zeitpunkt des Untersuchungszeitraums EPE entwickelte. Aufgrund der aufgetretenen, eingeschränkten Zuverlässigkeit des IPMA empfehlen die Autoren, für künftige Studien über die Antikörperkinetik bei L. intracellularis, sowie bei der serologischen Untersuchung als diagnostisches Mittel, alle Proben als Duplikat zu untersuchen, um verlässliche Ergebnisse über die Exposition des Fohlens gegenüber L. intracellularis zu erhalten.

Schlüsselwörter: Antikörperkinetik, Fohlen, IPMA, Lawsonia intracellularis, Serologie 